JEL Classification: R 13

\title{
ФІНАНСОВІ ІНСТРУМЕНТИ В СИСТЕМІ ЗАБЕЗПЕЧЕННЯ КОНКУРЕНТОСПРОМОЖНОСТІ РЕГІОНАЛЬНИХ ПРОМИСЛОВИХ КОМПЛЕКСІВ
}

\author{
Носирєв О.О., канд. геогр. наук, доцент \\ Національний технічний університет «Харківський політехнічний \\ інститут»" \\ Деділова Т.В., канд. екон. наук, доцент \\ Харківський національний автомобільно-дорожній університет \\ Осипова С.К., старший викладач \\ Національний технічний університет «Харківський політехнічний \\ інститут»"
}

Постановка проблеми. Для формування умов соціально-економічного розвитку країни важливим $є$ не лише розробка виваженої, реалістичної фінансової політики 3 урахуванням стратегічних пріоритетів, але й забезпечення ефективного управління фінансовим потенціалом регіональних промислових комплексів.

На сьогодні особливої ваги набуває аналіз фінансових інструментів стабілізації регіонального розвитку з метою його стимулювання та підвищення ділової активності, а також вирівнювання диспропорцій, що мають місце в сучасних умовах, адже це $\epsilon$ однією зі стратегічних цілей економічної безпеки держави в умовах децентралізації.

Аналіз останніх досліджень і публікацій. Питанням теорії, методології та практиці фінансування регіонального промислового розвитку присвячено багато наукових праць. Проблематика фінансового регулювання та фінансової стабілізації регіонів $є$ однією зі сфер досліджень таких науковців, як 3.В. Герасимчук, I.М. Вахович, I.М. Камінська [1], О.І. Амоша, І.П. Булєєв, Ю.С. Залознова [2], Д.А. Міщенко, Л.О. Міщенко, Д.О. Опошня [3], Н.В. Шемякіна [4], О.І. Дем'янчук [5], О.Я. Савко [6], О.І. Маслак [7], Л.В. Оболенцева [8, 13], І.М. Пушкарчук [9], М.С. Хомяк [10], Л. Дейнеко та Л. Ципліцька [11], І.В. Радзівіло [12], С.Я. Слецьких [14], Н.О. Власова та О.О. Носирєв [15], І.А. Шовкун [16]. Проте, поглиблення існуючих досліджень потребують механізми підвищення конкурентоспроможності промисловості регіону у взаємозв'язку із фінансовою стабілізацією регіональної економіки, що актуалізує дослідження у даному напрямку.

Невирішені складові загальної проблеми. Незважаючи на наявність широкого кола публікацій, низка питань, пов'язаних з розвитком промисловості в сучасних умовах та визначенням ролі держави в цьому процесі потребує подальших наукових пошуків. Зміни у зовнішньому середовищі, цикли 
розвитку національної економіки та галузеві особливості визначають необхідність спеціальних досліджень сучасного стану умов використання фінансових інструментів у забезпеченні регіонального промислового розвитку.

Потребує удосконалення інструментарій, який може бути використано на макро- та мезорівні органами влади 3 метою підвищення ефективності промислового комплексу, поліпшення умов функціонування промислових підприємств регіону, поліпшення інноваційно-інвестиційного розвитку промисловості.

Формулювання цілей статті. Метою дослідження $є$ вдосконалення системи застосування фінансових інструментів у процесах підвищення рівня конкурентоспроможності промисловості, регулювання та стабілізації регіонального промислового та економічного розвитку.

Виклад основного матеріалу дослідження. Відсутність бачення стратегічних перспектив подальшого розвитку вітчизняної промисловості призводить до стрімкого падіння техніко-технологічного потенціалу цієї найважливішої галузі економіки. Можна констатувати, що 3 боку органів державної влади та управління питанням розвитку промисловості в Україні приділяється недостатньо уваги. На сучасному етапі в України тенденції щодо регресу техніко-технологічного рівня промислового виробництва набирають сили. Концентрація зусиль органів державної влади на вирішенні поточних проблем затьмарює та перешкоджає розв'язання стратегічних питань промислового розвитку вітчизняного виробництва. Надається недостатньо уваги сприянню технічному розвитку підприємств на державному рівні [1].

Аналіз стану дослідження процесів фінансового забезпечення розвитку промисловості в сучасних умовах системних дисбалансів дозволяє дійти висновку, що ряд питань теоретичного та прикладного характеру залишаються невирішеними. Взагалі, відсутня цілісна концепція фінансування розвитку промисловості у новому інституціональному середовищі післякризового розвитку [4].

В загальному випадку, конкурентоспроможність промисловості та фінансова стабілізація регіону $\epsilon$ двома визначальними умовами його динамічного соціального, економічного й екологічного розвитку. Обидва ці явища характеризують стан регіональної економіки й асоціюються 3 економікою, що розвивається.

Фінансовий потенціал регіону є основою його економічного розвитку. У дослідженнях О. Дем'янчук [5] із використанням методу макроекономічної оцінки було визначено основні тенденції у розвитку регіонів України. Згідно 3 методом групування та оцінки коефіцієнту диференціації економічного розвитку регіонів встановлено, що для України характерна значна диспропорція розвитку ii регіонів за наявності біля десяти областей 3 досить низьким фінансовим потенціалом. Тому першочерговими положеннями у розробці регіональних програм та регіональної політики мають бути стабілізуючі заходи економічного розвитку цих регіонів та сприяння проведенню усіх державних 
реформ на регіональному рівні, які забезпечать ефективне використання як наявних, так й потенційних фінансових ресурсів, організаційних та управлінських складових фінансового потенціалу регіонів України [5].

За визначенням I. Пушкарчук [9], «конкурентоспроможність промисловості можна розуміти як іiі реальну та потенційну здатність розробляти, виготовляти, збувати і обслуговувати в конкретних сегментах ринку конкурентоспроможні товари, що за якісно-ціновими параметрами перевершують зарубіжні аналоги та користуються пріоритетним попитом у споживачів. Конкурентоспроможність промисловості (у сукупності з іншими галузями національної економіки) визначає регіональну і в цілому національну конкурентоспроможність». Вона також зазначає, що конкурентоспроможність промисловості регіону характеризує спроможність регіональних промислових виробників конкурувати зі своїми суперниками, що виробляють аналогічну продукцію, а у глобальному аспекті свідчить про можливість регіону експортувати конкурентоздатну промислову продукцію [9]. При цьому, конкурентоспроможність промисловості регіону, яка виражена в частині внутрішнього ринку промислової продукції, для вітчизняних промислових підприємств є індикатором визначеності, орієнтування на який забезпечує можливість концентрації інших видів ресурсів та їхнього використання для досягнення економічних інтересів.

Конкурентоспроможність базується на створенні регіональним промисловим комплексом наростаючого обсягу доданої вартості, підвищенні ефективності використання засобів виробництва, виходу на нові ринки, поліпшенні інноваційної складової продукції та інвестиційної привабливості підприємств, галузей та регіонів. Відповідно, конкурентоспроможність промисловості регіону $\epsilon$ загальним індикатором ринкової ефективності регіонального промислового комплексу [9].

Цікавою також $\epsilon$ думка I. Пушкарчук, в якій вона зазначає, що «конкурентоспроможність та фінансова стабілізація регіону є різновекторними, конфліктними цілями розвитку. Це пояснюється тим, що задля підвищення конкурентоспроможності промисловості регіону необхідна додаткова іммобілізація фінансових ресурсів 3 різноманітних джерел та резервів, що знижує рівень фінансової самостійності (стійкості) території. Тому досить часто високо конкурентоспроможні об'єкти характеризуються водночас високим рівнем фінансового ризику за поточними виробничо-господарськими операціями i, навпаки, об'єкти зі стабільно високими рівнями фінансових ресурсів повільно підвищують рівень конкурентоспроможності» [9].

Також можна погодитись 3 думкою Л. Оболенцевої, яка зазначає, що при розробці регіональної політики управління конкурентоспроможністю промислових підприємств необхідно дотримуватися певних умов:

- дотримання високого науково-технічного рівня i ступеню вдосконалення технологій виробництва;

- використання новітніх винаходів та відкриттів; 
- впровадження сучасних засобів автоматизації виробництва;

- вироблення конкурентоспроможної продукції, яка характеризується нормативними, технічними та економічними параметрами;

- забезпечення фінансової стійкості підприємств, що визначається системою показників та коефіцієнтами ділової активності підприємств, поточної ліквідності, автономії та ін. [8].

Фінансові інструменти, що впливають на активізацію діяльності промислових підприємств, та за допомогою яких держава здатна регулювати та стабілізувати регіональний промисловий розвиток, відображено на рис. 1.

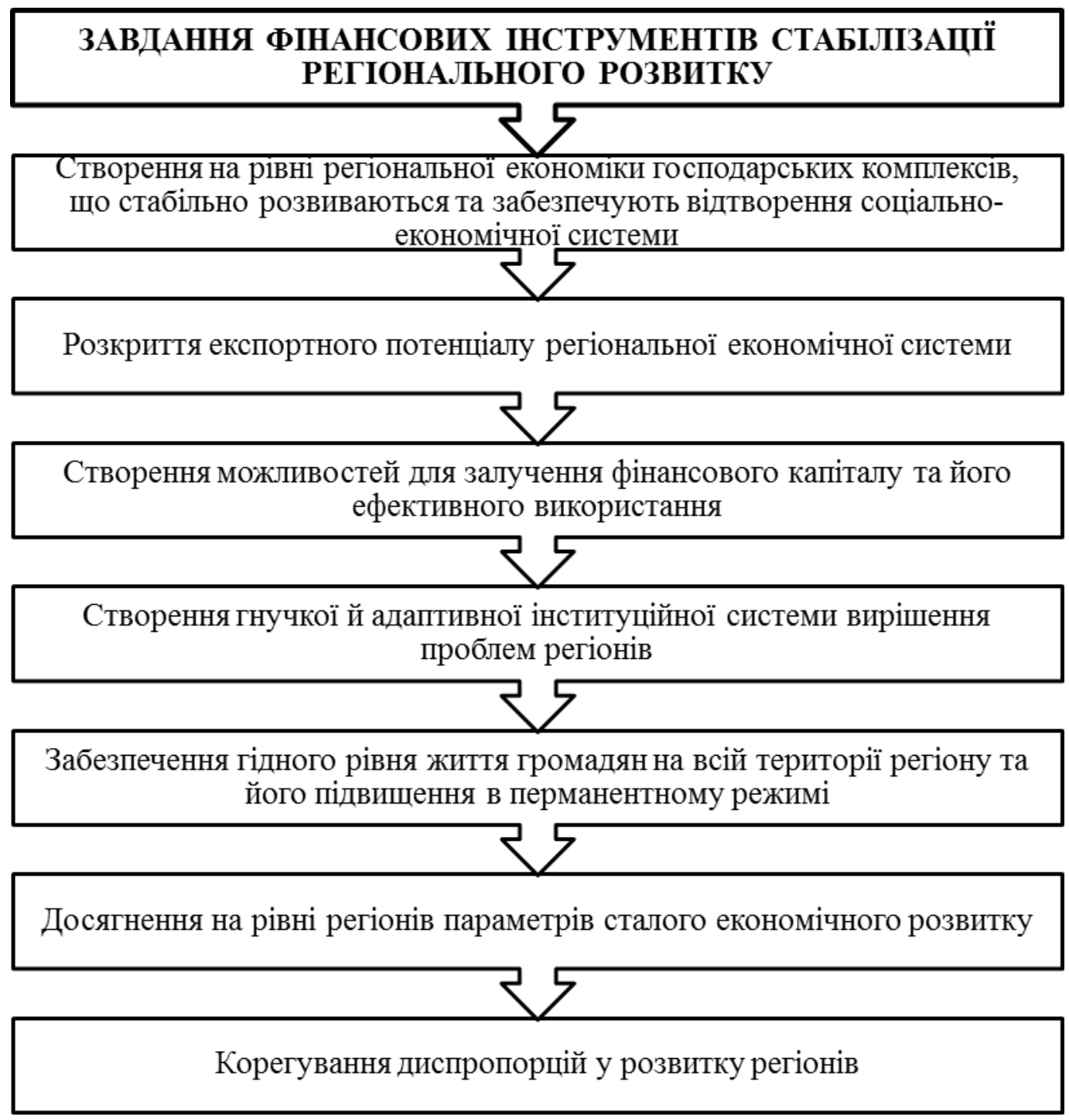

\section{Рис. 1. Стабілізаційні ефекти використання фінансових інструментів регіонального розвитку \\ Джерело: розроблено авторами}

Для забезпечення поставлених завдань необхідним $є$ комплекс фінансових інструментів стабілізації регіонального економічного розвитку, який відображено нижче (рис. 2). 


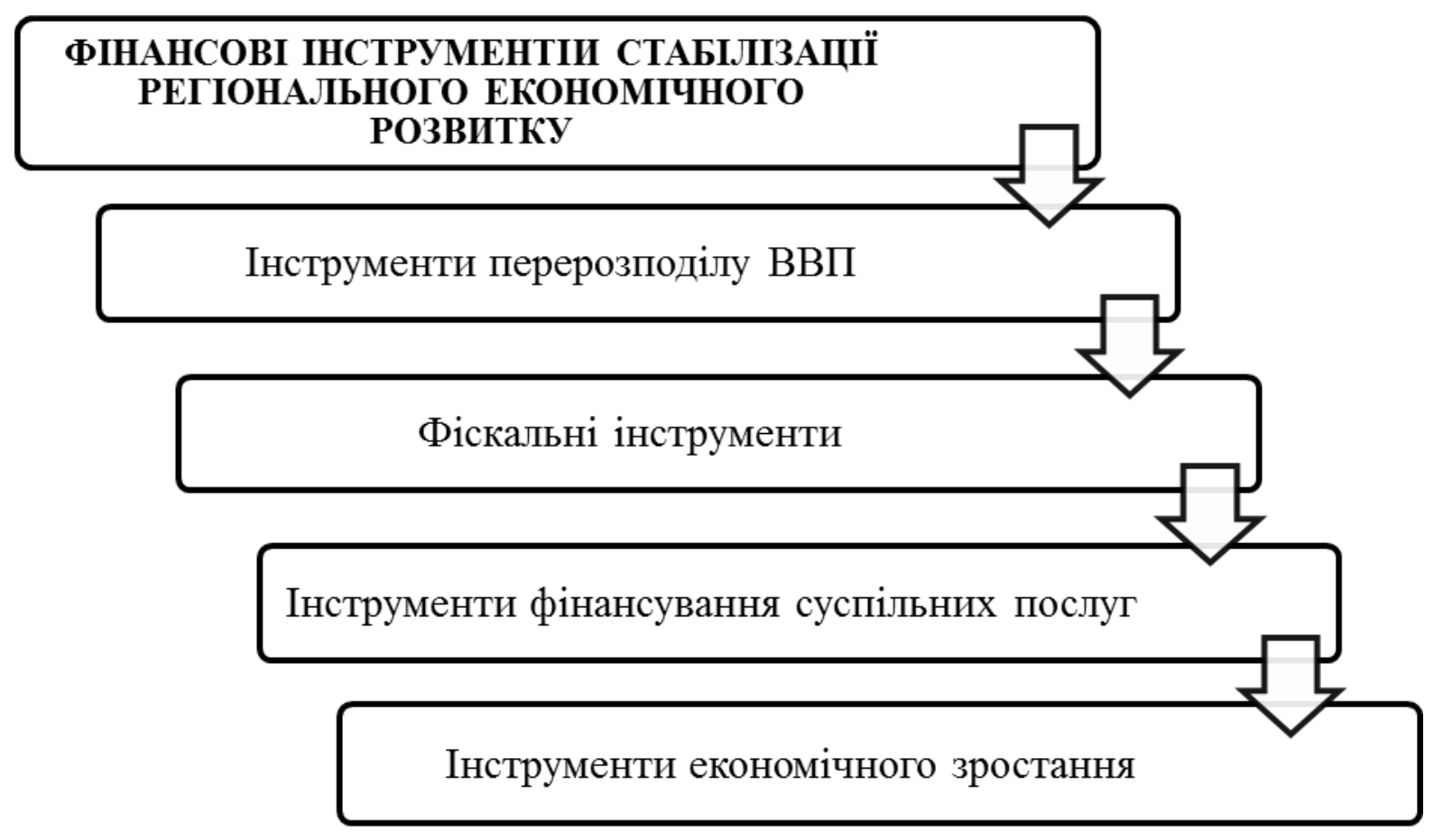

\section{Рис. 2. Фінансовий інструментарій стабілізації регіонального економічного розвитку \\ Джерело: узагальнено авторами}

Збільшення притоку інвестицій є пріоритетним у забезпеченні розвитку регіонів. Саме вони є рушійним фактором розвитку та акумулятором значних за обсягами ресурсів, яких, зазвичай, немає в регіоні, та які не можуть надати кредитні інституції [10].

На думку Л. Дейнеко та О. Циплянської, наявний фінансовий потенціал регіонів вже в короткостроковому періоді дозволяє забезпечити вдвічі більший обсяг інвестицій в основний капітал, ніж є на поточний момент. Сукупні інвестиції можуть бути сформовані за рахунок капітальних інвестицій, прямих іноземних інвестицій та кредитних ресурсів, джерелом яких виступають депозити у фінансових установах. Однак необхідною умовою $є$ зниження ставки банківських кредитах [11].

В умовах ринкової економіки однією 3 основних складових економічного забезпечення стабільності та розвитку діяльності є достатність фінансових ресурсів. Промислові підприємства як ключові гравці інноваційного сектору повинні теж постійно вишикувати різноманітні джерела фінансування, користуючись фінансовими інструментами процесів промислового розвитку в економіці України досить обмежені, адже вони прямопропорційно пов'язані з фінансами підприємств та фінансами населення. Фінансові інструменти забезпечують приплив капіталу з одних галузей в інші, а також мобілізують грошові кошти інвесторів [12].

Нові виклики регіонального розвитку, такі як поглиблення просторових диспропорцій, економічний занепад тимчасово окупованих територій 
Луганської, Донецької областей, Автономної Республіки Крим, проведення реформи децентралізації як засіб часткового вирішення проблеми реінтеграції регіонів, перехід від вертикальної (секторальної) до горизонтальної промислової політики в Україні, а також наявний промисловий та інвестиційний потенціал регіонів створюють необхідність зміни завдань регіональної промислової політики. Це обумовить зсув фокусу регіональної промислової політики 3 підтримання «на плаву» існуючих промислових підприємств на комплексну реструктуризацію економік регіонів [11].

Авторське узагальнення механізму та інструментарію підвищення конкурентоспроможності промисловості регіонів надано на рис. 3.

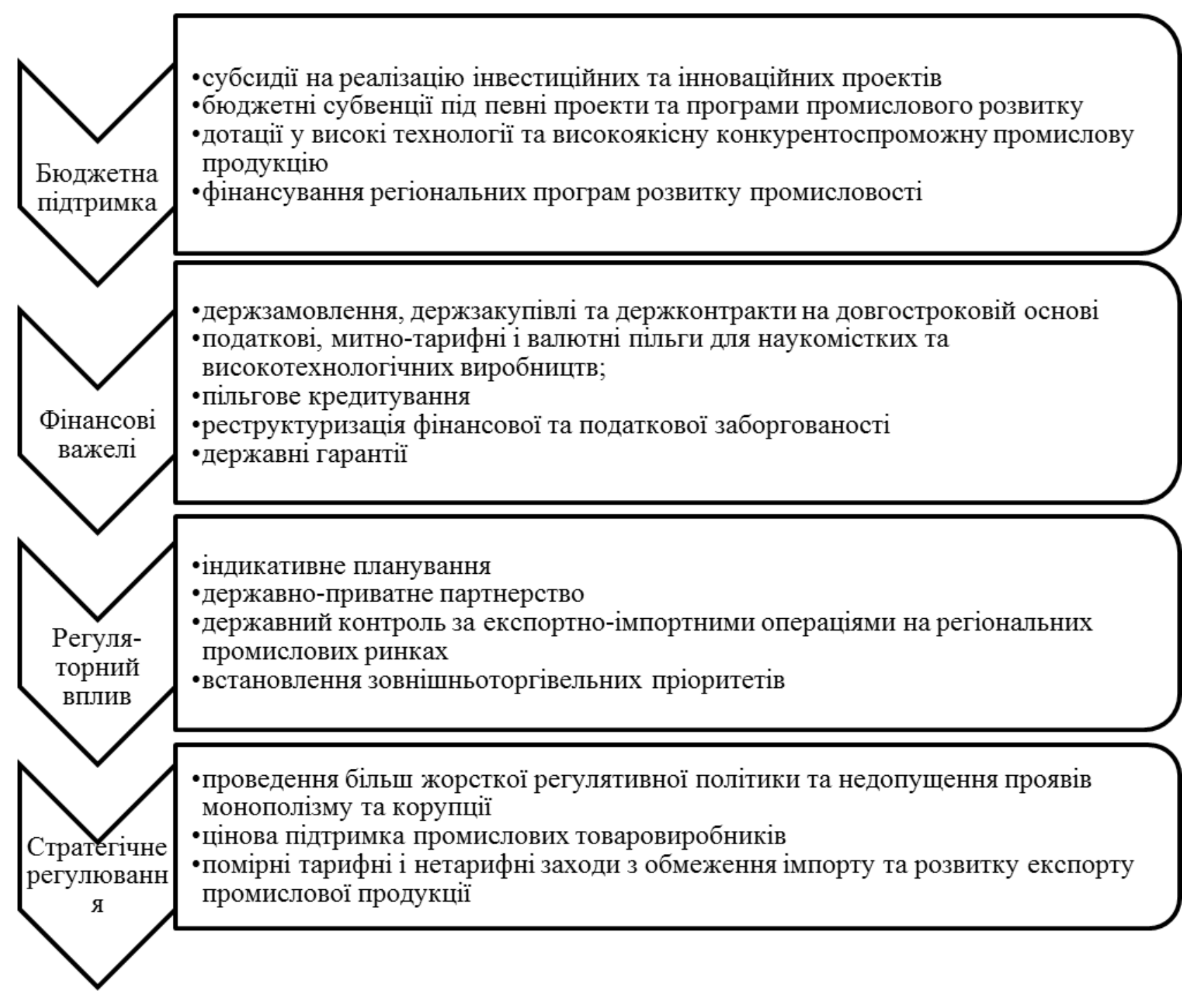

Рис. 3. Механізм та інструментарій підвищення конкурентоспроможності промисловості регіонів Джерело: розроблено авторами

Нові завдання регіональної промислової політики випливають із сучасних парадигм неоіндустріальної, інноваційної економіки та промислової політики. 
Вони передбачають використання таких інструментів як програми горизонтальної підтримки промислового розвитку регіонів, моніторинг стану промислових підприємств, заходи із інклюзії регіонального промислового комплексу в міжрегіональні та глобальні виробничі ланцюги.

Науковиця I. Пушкарчук [9] наводить такі передумови посилення ефективності підвищення конкурентоспроможності промисловості регіонів:

- реструктуризація промисловості;

- модернізація промислової інфраструктури та галузей промисловості;

- поліпшення підприємницького середовища та активізація регіональної інвестиційно-інноваційної політики;

- створення мережі інноваційних кластерів 3 виробництва конкурентоспроможної продукції;

- активізація прогресивних структурних зрушень та формування оптимальної структури промисловості в регіоні;

- орієнтація на випуск нової промислової продукції та розширення експортного потенціалу регіону та організованих збутових мереж;

- формування та реалізація стратегії підвищення конкурентоспроможності промисловості регіону [9].

У дослідженні С. Слецьких [14] зазначається, що «підприємства промисловості України мають суттєві проблеми щодо забезпечення фінансової стійкості, що обумовлено, насамперед, недостатнім та неефективним управлінням структурою їхнього капіталу та активів.

У результаті оцінки фінансової стійкості підприємств промисловості України на основі використання часткових показників стає можливим визначення таких суттєвих проблем, пов’язаних: по-перше, з інтерпретацією результатів розрахунків окремих часткових показників фінансової стійкості; по-друге, з неоднозначністю оцінки результатів розрахунків, яка виявляється у тому, що частина показників певної групи характеризує фінансову стійкість 3 позитивного боку (наприклад, структура капіталу), а інша частина - 3 негативного (наприклад, структура активів), що призводить до неможливості надати однозначне тлумачення рівня фінансової стійкості» [14].

Особливості сучасного розвитку національної економіки, обумовлені значною мінливістю та, в певній мірі, невизначеністю ринкових перетворень, що пов'язані 3 подоланням наслідків кризових явищ в Україні на фоні загальносвітових глобалізаційних тенденцій, які посилюють залежність ефективності функціонування підприємств усіх галузей від стану та динаміки макроекономічного середовища. Коливання у зовнішньому середовищі можуть різко змінювати фінансові результати підприємств і навіть приводити їх до банкрутства. Факторами впливу зовнішнього оточення можуть бути процентні ставки, обмінні курси, ціни на ресурси та продукцію, ціни акцій й ін. Причому підприємство, на яке впливають зміни фінансових цін, зовсім не обов'язково має бути безпосередньо пов'язано з ринком, на якому змінюються ці ціни. Наприклад, підприємство може зовсім не використовувати зовнішнє 
фінансування й може не володіти чутливими до процентних ставок активами. Однак воно, проте, може піддаватися значним процентним ризикам [15].

Дослідження та досвід розвинутих країн доводять, що активізація інвестиційного розвитку промислової діяльності можлива тільки на основі розвиненої системи фінансування, що покликана забезпечувати вирішення таких найважливіших завдань: збереження i розвиток інноваційнопромислового потенціалу в стратегічних та пріоритетних напрямах розвитку; створення необхідних передумов для своєчасного й ефективного впровадження технічних та технологічних новацій в усіх сферах національної економіки, забезпечення іiі структурно-технологічної перебудови; створення необхідних матеріальних умов для збереження кадрового наукового потенціалу, запобігання його відтоку за кордон [4].

Висновки 3 проведеного дослідження. Фінансові обмеження (нестача у підприємств власних фінансових ресурсів та недоступність зовнішніх джерел фінансування) залишаються важливим чинником, що стримує розвиток та підвищення рівня конкурентоспроможності промислових підприємств.

Наявною $€$ пряма залежність між рівнями конкурентоспроможності промисловості та фінансової стабілізації регіону: чим більш конкурентоспроможною є промисловість регіону, тим вищий рівень фінансової стабілізації характеризує даний регіон. Підгрунтям реалізації інноваційноінвестиційних можливостей підприємств промисловості, що визначають рівень конкурентоспроможності в мінливих ринкових умовах, $\epsilon$ фінансове забезпечення поточних та стратегічних планів розвитку.

Домінування механізмів самофінансування та обмеженість зовнішніх джерел залучення коштів промисловими підприємствами призводять до консервації існуючої технологічної структури економіки, не забезпечують перерозподіл фінансових ресурсів у наукоємні технології промисловості, гальмують прогресивні структурні зрушення. Існує нагальна потреба в удосконаленні механізмів фінансування регіонального промислового розвитку в економіці України.

Для підвищення конкурентоспроможності промисловості регіонів України необхідно вдосконалити наявні та розробити нові дієві регіональні стратегії розвитку промислових комплексів та механізми управління їхньою конкурентоспроможністю, які будуть адаптивними в залежності від характеру змін у зовнішньому середовищі.

Всі ці аспекти потребують подальших досліджень, теоретичного узагальнення й методичного обгрунтування, конкретизації для сучасних умов розвитку промисловості України.

\section{Перелік посилань}

1. Герасимчук 3. В., Вахович I. М., Камінська I. М. Фінансова політика сталого розвитку регіону. Луцьк : Надстир'я, 2006. 220 с.

2. Амоша О. І., Булєєв І. П., Залознова Ю. С та ін. Промисловість України 2014-2016: невикористані можливості, шляхи відновлення, модернізації та 
сучасної розбудови. Київ : Ін-т економіки промисловості НАН України, 2017. $553 \mathrm{c}$.

3. Міщенко Д. А., Міщенко Л. О., Холошня Д. О. Державна фінансова підтримка розвитку промисловості України як метод подолання фінансової кризи. Економіка та держава. 2017. № 11. С. 15-20.

4. Шемякіна Н. В. Шляхи удосконалення фінансового забезпечення розвитку промисловості. Проблеми економіки. 2013. № 3. С. 178-183.

5. Дем'янчук О. I. Фінансовий потенціал регіонів України як базова основа їх стабільного економічного розвитку. Наукові записки Національного університету «Острозька академія». Серія : Економіка. 2014. Вип. 27. С. 73-78. URL : http://nbuv.gov.ua/UJRN/Nznuoa_2014_27_15.pdf (дата звернення : 15.10.2020).

6. Савко О.Я. Класифікація фінансових стратегій промислових підприємств. Науковий вісник Ужсгородського наиіонального університету : Серія: Міжнародні економічні відносини та світове господарство. Ужгород: Гельветика. 2016. Вип.8. Ч. 2. С. 79-82.

7. Маслак О. I. Особливості оцінювання фінансового потенціалу промислового підприємства. Вісник КрНУ імені Михайла Остроградського. 2014. Випуск 6 (77). С. 124-129.

8. Оболенцева Л. В. Методи формування стратегії управління конкурентоспроможністю промислових комплексів регіонів. Бізнес Інформ. 2017. № 12. C. 413-418. URL : http://nbuv.gov.ua/UJRN/binf_2017_12_65 (дата звернення : 16.10 .2020$)$.

9. Пушкарчук I. M. Механізми підвищення конкурентоспроможності промисловості як основа фінансової стабілізації регіональної економіки . Ефективна економіка. 2016. № $3 . \quad$ URL http://nbuv.gov.ua/UJRN/efek_2016_3_40 (дата звернення : 10.10.2020).

10. Хомяк М. С. Фінансові інструменти стабілізації регіонального розвитку. Глобальні та національні проблеми економіки. 2016. № 9. С. 711-714. URL : http://global-national.in.ua/archive/9-2016/146.pdf (дата звернення : 15.10.2020).

11. Дейнко Л., Ципліцька О. Промисловий потенціал регіонів та завдання регіональної промислової політики в умовах реіндустріалізації. Економічний аналіз. 2020. № 30.1 (1). С. 65-73.

12. Радзівіло I. В. Фінансові інструменти забезпечення подолання кризи інноваційного розвитку промислових підприємств. Економічний вісник Національного гірничого університету. 2010. № 3. С. 66-74. URL : http://nbuv.gov.ua/UJRN/evngu_2010_3_12 (дата звернення : 11.10.2020).

13. Оболенцева Л. В. Інвестиційне забезпечення управління конкурентоспроможністю промислових комплексів регіонів. Соціальна економіка. 2018. Вип. 56. С. 190-196. URL http://nbuv.gov.ua/UJRN/se_2018_56_21 (дата звернення : 15.10.2020). 
14. Єлецьких С. Я. Удосконалення процесу управління фінансово стійким розвитком промислового підприємства. Економіка промисловості. 2012. № 3-4. C. 74-80. URL : http://nbuv.gov.ua/UJRN/econpr_2012_3-4_13 (дата звернення : 17.10.2020).

15. Власова Н. О. Вплив макроекономічних факторів на фінансові результати підприємств промисловості. Соціальна економіка. 2018. Вип. 56. C. 18-26. URL : http://nbuv.gov.ua/UJRN/se_2018_56_4 (дата звернення : 15.10.2020).

16. Шовкун I. А. Фінансове забезпечення інноваційної діяльності в контексті неоіндустріалізації економіки України. Фінанси України. 2014. № 12. C. 83-95. URL : http://nbuv.gov.ua/UJRN/Fu_2014_12_8 (дата звернення : 15.10.2020).

\section{References}

1. Gerasymchuk, Z., Vakhovych, I., Kaminska, I. (2006), Financial policy of sustainable development of the region [Finansova polityka staloho rozvytku rehionu], Nadstyria, Lutsk, 220 p.

2. Amosha, O., Buleev, P., Zaloznova, Yu. (2017), Industry of Ukraine 20142016: unused opportunities, ways of restoration, modernization and modern development [Promyslovist Ukrainy 2014-2016: nevykorystani mozhlyvosti, shliakhy vidnovlennia, modernizatsii ta suchasnoi rozbudovy], Institute of Industrial Economics of the National Academy of Sciences of Ukraine, Kyiv, 553 p.

3. Mishchenko, D., Mishchenko, L., Kholoshnya, D. (2017), "State financial support of industrial development of Ukraine as a method of overcoming the financial crisis" ["Derzhavna finansova pidtrymka rozvytku promyslovosti Ukrainy yak metod podolannia finansovoi kryzy"], Economy and state, No. 11, P. 15-20.

4. Shemyakina, N. (2013), "Ways to improve the financial support of industrial development" ["Shliakhy udoskonalennia finansovoho zabezpechennia rozvytku promyslovosti"], Problems of Economics, No. 3, P. 178-183.

5. Demyanchuk, O. (2014), "Financial potential of the regions of Ukraine as a basic basis of their stable economic development" ["Finansovyj potencial rehioniv Ukrajiny jak bazova osnova jix stabil'noho ekonomičnoho rozvytku"], available at : http://nbuv.gov.ua/UJRN/Nznuoa_2014_27_15.pdf (last accessed 15.10.2020).

6. Savko, O. Ya. (2016), "Classification of financial strategies of industrial enterprises" ["Klasyfikatsiia finansovykh stratehii promyslovykh pidpryiemstv"], Scientific herald of the Uzhhorod National University: Series: International economic relations and world economy, Helvetica, Uzhhorod, No. 8(2), P. 79-82.

7. Maslak, O. I. (2014), "Peculiarities of evaluating the financial potential of an industrial enterprise" ["Osoblyvosti otsiniuvannia finansovoho potentsialu promyslovoho pidpryiemstva"], Bulletin of Mykhailo Ostrohradskyi KrNU, No. 6 (77), P. 124-129.

8. Obolentseva, L. V. (2017), "Methods of forming the strategy of managing the competitiveness of industrial complexes of regions" ["Metody formuvannia stratehii upravlinnia konkurentospromozhnistiu promyslovykh kompleksiv 
rehioniv"], Business Inform, No. 12, P. 413-418, available at : http://nbuv.gov.ua/UJRN/se_2018_56_21 (last accessed 16.10.2020).

9. Pushkarchuk, I. M. (2016), "Mechanisms of increasing the competitiveness of industry as the basis of financial stabilization of the regional economy" ["Mekhanizmy pidvyshchennia konkurentospromozhnosti promyslovosti yak osnova finansovoi stabilizatsii rehionalnoi ekonomiky"], Effective economy, No. 3, available at : http://nbuv.gov.ua/UJRN/efek_2016_3_40 (last accessed 10.10.2020).

10. Khomyak, M. S. (2016), "Financial instruments for stabilizing regional development" ["Finansovi instrumenty stabilizatsii rehionalnoho rozvytku"], Global and national economic problems, No. 9, P. 711-714, available at : http://globalnational.in.ua/archive/9-2016/146.pdf (last accessed 15.10.2020).

11. Dejneko, L, Tsyplitska, O. (2020), "Industrial potential of regions and tasks of regional industrial policy in the conditions of reindustrialization" ["Promyslovyi potentsial rehioniv ta zavdannia rehionalnoi promyslovoi polityky $\mathrm{v}$ umovakh reindustrializatsii"], Economic Analysis, No. 30.1 (1), P. 65-73.

12. Radzivilo, I.V. (2010), "Financial instruments for overcoming the crisis of innovative development of industrial enterprises" ["Finansovi instrumenty zabezpechennia podolannia kryzy innovatsiinoho rozvytku promyslovykh pidpryiemstv"], Economic Bulletin of the National Mining University, No 3, P. 66-74, available at : http://nbuv.gov.ua/UJRN/evngu_2010_3_12 (last accessed 11.10.2020).

13. Obolentseva, L. V. (2018), "Investment support of competitiveness management of industrial complexes of regions" ["Investytsiine zabezpechennia upravlinnia konkurentospromozhnistiu promyslovykh kompleksiv rehioniv"], Social economy, No. 56, P. 190-196, available at : http://nbuv.gov.ua/UJRN/se_2018_56_21 (last accessed 15.10.2020).

14. Jelec'kyx, S. Ya. (2012), "Improving the process of managing the financially sustainable development of an industrial enterprise" ["Udoskonalennia protsesu upravlinnia finansovo stiikym rozvytkom promyslovoho pidpryiemstva"], Industrial economics, No. 3-4, P. 74-80, available at : http://nbuv.gov.ua/UJRN/econpr_2012_3-4_13 (last accessed 17.10.2020).

15. Vlasova, N. O., Nosyriev, O. O. (2018), "Influence of macroeconomic factors on the financial results of industrial enterprises" ["Vplyv makroekonomichnykh faktoriv na finansovi rezultaty pidpryiemstv promyslovosti"], Social economy, No. 56, P. 18-26, available at : http://nbuv.gov.ua/UJRN/se_2018_56_4 (last accessed 15.10.2020).

16. Shovkun, I. A. (2014), "Financial support of innovation activity in the context of neo-industrialization of the economy of Ukraine" ["Finansove zabezpechennia innovatsiinoi diialnosti $\mathrm{v}$ konteksti neoindustrializatsii ekonomiky Ukrainy"], Finance of Ukraine, No. 12, P. 83-95, available at : http://nbuv.gov.ua/UJRN/Fu_2014_12_8 (last accessed 15.10.2020). 


\title{
РЕФЕРАТИ РЕФЕРАТЫ ABSTRACTS
}

\section{УДК 336:338; JEL Classification: R 13}

\section{Носирсв О. О., Деділова Т. В., Осипова С. К. ФІНАНСОВІ IНСТРУМЕНТИ В В ИСТЕМI КОНКУРЕНТОСПРОМОЖНОСТІ РЕГІОНАЛЬНИХ ПРОМИСЛОВИХ КОМПЛЕКСІВ}

\author{
Mema. Метою дослідження $є$ вдосконалення системи застосування
} фінансових інструментів у процесах підвищення рівня конкурентоспроможності промисловості, регулювання та стабілізації регіонального промислового та економічного розвитку. Методика дослідження. Для досягнення зазначеної мети у роботі використано методи аналізу та синтезу, які було застосовано при аналізі сучасного стану використання фінансових важелів стимулювання промисловості регіонів. Результати. У роботі досліджено систему фінансового інструментарію забезпечення конкурентоспроможності промисловості та активізації розвитку регіональних промислових комплексів. Досліджено механізми підвищення конкурентоспроможності промисловості регіону у взаємозв'язку із фінансовою стабілізацією регіональної економіки. Визначено, що фінансова стабільність промислових підприємств $є$ рівноважним станом, перебуваючи у якому промисловий комплекс спроможний формувати фінансові ресурси у достатньому обсязі та забезпечувати соціально-економічний розвиток, оперативно реагувати на зміни ринкової кон'юнктури. Запропоновано інструментарій та механізм підвищення конкурентоспроможності промисловості регіонів. Узагальнено основні проблеми регіонального розвитку регіонів України (нерівномірний економіко-соціальний розвиток областей, розбалансованість у техногенному навантаженні на окремі території, значні обсяги первинного ресурсоспоживання, орієнтованість окремих територій на сировинну та переробну галузь, затратний тип виробництва). Виявлено існування прямої залежності між рівнями конкурентоспроможності промисловості та фінансової стабілізації регіону. Запропоновано комплексне використання фінансового інструментарію активізації діяльності промислових підприємств, системність застосування якого матиме вплив на регулювання та стабілізацію регіонального промислового розвитку. Наукова новизна. У ході наукового дослідження було вдосконалено теоретико-методологічні основи фінансового інструментарію активізації регіональних промислових комплексів, зокрема, запропоновано авторське бачення системи стабілізаційних ефектів використання фінансових інструментів регіонального розвитку. Практична значущість. Сферою застосування результатів дослідження $\epsilon$ система управління промисловістю на рівні держави та регіонів, що сприятиме економічному розвитку i функціонуванню держави на належному рівні. Результати можуть бути використані органами державної та місцевої влади при розробці програм стимулювання та розвитку промислових комплексів та програм регіонального економічного розвитку. 
Ключові слова: промисловість; фінансове регулювання; регіональний розвиток; промислова політика; фінансовий потенціал; промисловий розвиток.

УДК 336:338; JEL Classification: R 13

Носырев А. А., Дедилова Т. В., Осипова С. К. ФИНАНСОВЫЕ
ИНСТРУМЕНТЫ
КОНКУРЕНТОСПОСОБНОСТИ
ПРОМЫШЛЕННЫХ КОМПЛЕКСОВ

Цель. Целью исследования является совершенствование системы применения финансовых инструментов в процессах повышения конкурентоспособности промышленности, регулирования и стабилизации регионального промышленного и экономического развития. Методика исследования. Для достижения указанной цели в работе использованы методы анализа и синтеза, которые были применены при исследовании современного состояния использования финансовых рычагов стимулирования промышленности регионов. Результаты. В работе исследована система финансового инструментария обеспечения конкурентоспособности промышленности и активизации развития региональных промышленных комплексов. Исследованы механизмы повышения конкурентоспособности промышленности региона во взаимосвязи с финансовой стабилизацией региональной экономики. Установлено, что финансовая стабильность промышленных предприятий является равновесным состоянием, находясь в котором промышленный комплекс способен формировать финансовые ресурсы в достаточных объемах и обеспечивать социально-экономическое развитие, оперативно реагировать на изменения рыночной конъюнктуры. Предложен инструментарий и механизм повышения конкурентоспособности промышленности регионов. Обобщены основные проблемы регионального развития регионов Украины (неравномерное социально-экономическое развитие областей, разбалансированность в техногенной нагрузке на отдельные территории, значительные объемы первичного ресурсопотребления, ориентированность отдельных территорий на сырьевую и перерабатывающую отрасли, затратный тип производства). Выявлено существование прямой зависимости между уровнями конкурентоспособности промышленности и финансовой стабилизации регионов. Предложено комплексное использование финансового инструментария активизации деятельности промышленных предприятий, системность применения которого позитивно повлияет на регулирование и стабилизацию регионального промышленного развития. Научная новизна. В ходе научного исследования были усовершенствованы теоретико-методологические основы финансового инструментария активизации региональных промышленных комплексов, в частности, предложено авторское видение системы стабилизационных эффектов использования финансового инструментария регионального промышленного развития. Практическая значимость. Сферой применения результатов исследования является система управления промышленностью на уровне государства и регионов, что может 
способствовать экономическому развитию и функционированию государства на современном уровне. Результаты могут быть использованы органами государственной и местной власти при разработке программ стимулирования и развития промышленных комплексов и программ регионального экономического развития.

Ключевые слова: промышленность; финансовое регулирование; региональное развитие; промышленная политика; финансовый потенциал; промышленное развитие.

\section{UDC 336:338; JEL Classification: R 13}

Nosyriev O., Dedilova T., Osypova S. FINANCIAL INSTRUMENTS IN THE SYSTEM OF COMPETITIVENESS OF REGIONAL INDUSTRIAL COMPLEXES

Purpose. The aim of the study is to improve the system of application of financial instruments in the processes of increasing the competitiveness of industry, regulation and stabilization of regional industrial and economic development. Research methodology. To achieve this goal, the methods of analysis and synthesis were used in the work, which were used in the study of the current state of use of financial levers to stimulate the industry of the regions. Findings. The system of financial tools for ensuring the competitiveness of industry and intensifying the development of regional industrial complexes is studied in the work. The mechanisms of increasing the competitiveness of the region's industry in connection with the financial stabilization of the regional economy are studied. It is established that the financial stability of industrial enterprises is an equilibrium state, in which the industrial complex is able to form financial resources in sufficient quantities and ensure socio-economic development, to respond quickly to changes in market conditions. The tools and the mechanism of increase of competitiveness of the industry of regions are offered. The main problems of regional development of regions of Ukraine are summarized (uneven socio-economic development of regions, imbalance in technogenic load on separate territories, considerable volumes of primary resource consumption, orientation of separate territories on raw and processing industries, cost type of production). The existence of a direct relationship between the levels of industrial competitiveness and financial stabilization of the regions has been revealed. The complex use of financial tools to intensify the activities of industrial enterprises is proposed, the systematic application of which will positively affect the regulation and stabilization of regional industrial development. Originality. In the course of scientific research the theoretical and methodological bases of financial tools for the activation of regional industrial complexes were improved, in particular, the author's vision of the system of stabilization effects of the use of financial tools for regional industrial development was proposed. Practical value. The scope of the research results is the system of industrial management at the level of the state and regions, which can contribute to the economic development and functioning of the state at the modern level. The 
results can be used by state and local authorities in developing programs to stimulate and develop industrial complexes and regional economic development programs.

Key words: industry; financial regulation; regional development; industrial policy; financial potential; industrial development.

\section{Відомості про авторів / Сведения об авторах / About the Authors}

Носирєв Олександр Олександрович - кандидат географічних наук, доцент, Національний технічний університет «Харківський політехнічний інститут», доцент кафедри міжнародного бізнесу та фінансів, м. Харків, Україна; e-mail: nosyriev.bf@khpi.edu.ua; ORCID ID: http://orcid.org/0000-00034089-3336. моб. 066-716-70-27.

Носырев Александр Александрович - кандидат географических наук, доцент, Национальный технический университет «Харьковский политехнический інститут», доцент кафедры международного бизнеса и финансов, г. Харьков, Украина; e-mail: nosyriev.bf@khpi.edu.ua; ORCID ID: http://orcid.org/0000-0003-4089-3336. моб. 066-716-70-27.

Nosyriev Oleksandr - PhD, Associate Professor, National Technical University "Kharkiv Polytechnic Institute", Associate Professor of the Department of International Business and Finance, Kharkiv, Ukraine.

Деділова Тетяна Вікторівна - кандидат економічних наук, доцент, Харківський національний автомобільно-дорожній університет, доцент кафедри економіки і підприємництва, м. Харків, Україна; e-mail: dedilova@ukr.net; ORCID: https://orcid.org/0000-0002-3924-979X. Моб. 050-281-83-28.

Дедилова Татьяна Викторовна - кандидат экономических наук, доцент, Харьковский национальный автомобильно-дорожный университет, доцент кафедры экономики и предпринимательства, г. Харьков, Украина.

Dedilova Tetiana - PhD in Economics, Associate Professor, Kharkiv National Automobile and Highway University, Associate Professor of the Department of Economics and Entrepreneurship, Kharkiv, Ukraine.

Осипова Світлана Костянтинівна - старший викладач, Національний технічний університет «Харківський політехнічний інститут», старший викладач кафедри міжнародного бізнесу та фінансів, м. Харків, Україна; e-mail: Svitlana.Osipova@khpi.edu.ua; ORCID ID: https://orcid.org/0000-0002-2381-1901. моб. 063-042-64-80.

Осипова Светлана Константиновна - старший преподаватель, Национальный технический университет «Харьковский политехнический інститут», старший преподаватель кафедры международного бизнеса и финансов, г. Харьков, Украина.

Osypova Svitlana - Senior Lecturer, National Technical University "Kharkiv Polytechnic Institute", Senior Lecturer of the Department of International Business and Finance, Kharkiv, Ukraine. 